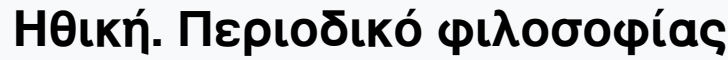

Ap. $13(2020)$

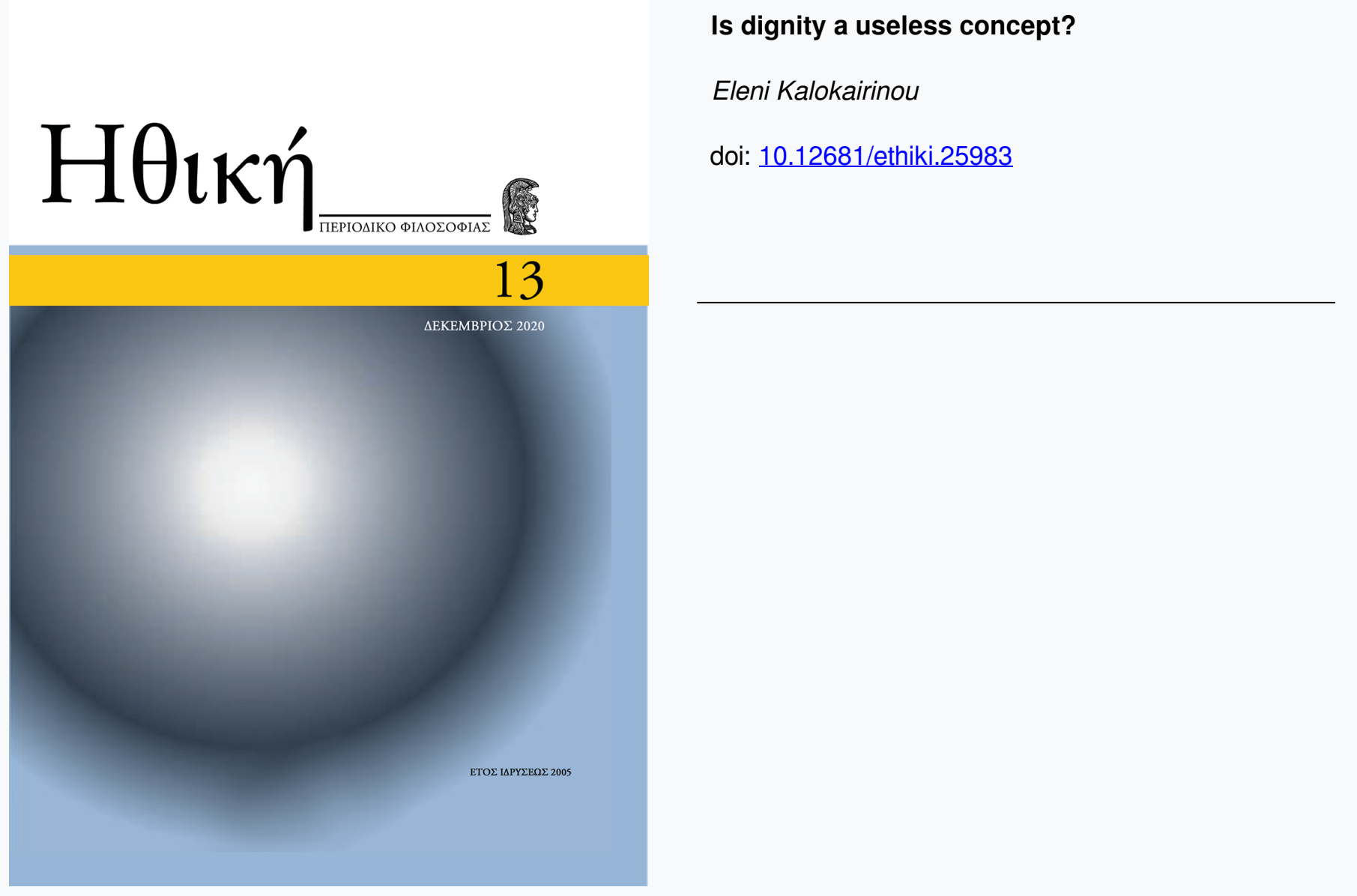

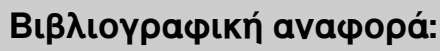

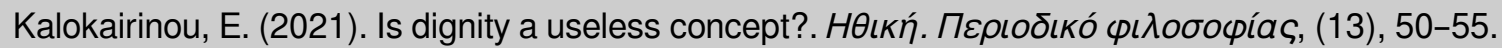

https://doi.org/10.12681/ethiki.25983 


\title{
Is dignity a useless concept?
}

\author{
ELENI Kalokairinou \\ Aristotle University of Thessaloniki \\ https://orcid.org/0000-0003-1486-2819
}

\begin{abstract}
In this paper I undertake to examine Ruth Macklin's claim that dignity is a useless concept. I explain her contention by the fact that dignity, as a concept, has a long history and has been presented differently at different times. I shed some light on certain different conceptions of dignity in ancient times and in our contemporary era. And I end up with the suggestion that the term "dignified", like "good", is a primarily evaluative term, unlike what some philosophers have thought.
\end{abstract}

Keywords: Dignity; autonomy; human rights; primarily and secondarily evaluative terms

In a short article under the title, "Dignity is a useless concept" the American bioethicist Ruth Macklin puts forward the claim that, contrary to what is usually thought, dignity is a useless concept and that all appeals to it are "either vague restatements of other, more precise, notions or mere slogans that add nothing to an understanding of the topic"1. In a positive formulation of her contention she argues that dignity "means no more than respect for persons or their autonomy" 2 . According to the American bioethicist therefore, dignity is either an empty concept which means nothing or a mere restatement of more precise concepts such as respect for persons or for their autonomy. As it stands, that is to say, dignity means nothing at all. It has therefore either no or very little use in discussions in bioethics.

John Harris, the British bioethicist, seems to argue in somewhat the same spirit, when he examines whether the technology of cloning affects human dignity in any way $^{3}$.

One reason which explains the confusion that surrounds this concept is that dignity has been used since antiquity in a number of contexts and has acquired different kinds of meanings. The concept of dignity can be traced back to the ancient philosophical texts, in particular in the works of Plato and Aristotle, in the Roman writers and philosophers, notably in Cicero, and later on in the texts of the Christian religion ${ }^{4}$. It can also be detected in civilizations which are older than the ancient Greek, like for instance the Chinese ${ }^{5}$. As Andorno points out, even though dignity is a concept of the Western civilization, nevertheless it has its correlates in the Confucian philosophy and thought ${ }^{6}$. As he puts it, "Confucianism has given substantive content to the notion of dignity in classic Chinese philosophy by establishing the 
moral ideals of humanity (Ren) and righteousness (Yi), as exemplified in the moral character of the Confucian gentleman (jünzi), the prototype of the virtuous man" was further analyzed and developed by the two famous writers of the Italian Renaissance, Giannozzo Manetti and Giovanni Pico Della Mirandola. The latter composed the treatise, Oratio Elegantissima de Dignitate Hominis, which has remained as one of the classical writings on dignity ${ }^{8}$.

However, it reached the peak of its development in Europe in modern times under the influence of Descartes' metaphysics and Kant's ethical thought. In the contemporary era, bioethicists have been studying it further in an attempt they make to bring out its relationship with autonomy and human rights not only in the context of political authority but also in the context of bioethics in which autonomy and human rights may be often put at risk by various medical practices and technologies. In this way the Universal Declaration of Human Rights (UDHR), which was issued in 1948, gives a pre-eminent place to human dignity, when it writes at the very beginning of its Preamble: Whereas recognition of the inherent dignity and of the equal and inalienable rights of all members of the human family is the foundation of freedom, justice and peace in the world'.

In a similar manner, the Universal Declaration in Bioethics and Human Rights issued by Unesco in 2005 considers human dignity and human rights as its superior principles, when it states: Human dignity, human rights and fundamental freedoms are to be fully respected ${ }^{10}$.

Furthermore, human dignity and human rights constitute its main aim the promotion of which the Declaration has undertaken to realize ${ }^{11}$.

Before we proceed to refute Macklin's contention we mentioned above, a couple of distinctions are apposite at this place. First, we must distinguish between dignity as is normally understood nowadays and the concept of dignity as was employed in the Roman times and in Cicero's writings. The Roman equivalent to dignity dignitas, dignitatis is the honor we attribute to someone, usually a general, an official or an important person, when he has excelled in bravery during the war or in some other feat. In this case, dignity is something which is awarded to someone and which he cannot acquire by himself. Dignity, on the other hand, as is traditionally understood and as is conceived in the contemporary era, is something we possess inherently by the mere fact that we are born human, and nobody else, apart from ourselves, can either deprive us of it or help us develop it. Dignity, as we conceive the concept in the modern era, is an inherent ability or predisposition which we will either develop ourselves or contribute to its elimination.

Secondly, we must distinguish between the two different ways in which dignity has been used throughout the centuries. As Ludwig Siep points out, we must distinguish between a transcendental and an inherent foundation of dignity ${ }^{12}$. The former can be traced back to the classical Greek philosophers Plato and Aristotle and the Christian tradition. According to Siep, it was the Platonic dualism that contributed mostly to this conception of dignity ${ }^{13}$. According to Plato, man participates through the intellectual part of his soul in the world of Ideas which is also the sphere of gods ${ }^{14}$. 
The value of this immaterial and intellectual part of man is undoubtedly bigger than the value of the material world. Man's dignity depends on the extent to which man succeeds in promoting this intellectual part of his self, despite the fetters that imposes on him his natural constitution ${ }^{15}$.

Aristotle does not agree with Plato's dualism nor with his contention that we participate in the mortal world as well as in the world of gods. Even so, however, Aristotle holds that all human beings share with gods the intellectual activity of their soul $^{16}$. Even though this activity cannot safeguard man's immortality, nevertheless to the extent that it renders man divine, like god, is a source of value, the root of man's dignity ${ }^{17}$.

But Siep also detects a second conception of dignity in Aristotle's work. It is the kind of psychophysical state man acquires, when his practical reason succeeds in controlling and guiding his desires and passions ${ }^{18}$. This is the kind of dignity one achieves after the unceasing exercise of one's practical reason over one's passions. Whereas the previous one is the kind of dignity one achieves through the intellectual activity of one's soul which likens one with gods.

It is interesting to notice at this point that, according to Siep, Aristotle conceives of dignity either as an intellectual activity in which only gods and very few exceptional men engage or as an exercise of practical reason with which only the virtuous men are occupied. Consequently, according to Siep's interpretation, Aristotle's eudaimon $(\varepsilon \dot{\delta} \delta a i ́ \mu \omega)$ character is the man who possesses dignity in one way or another.

The conception of dignity is further enhanced, according to Siep, by the influence of the Christian religion. In addition to his intellectual aspect which he shares with God, man also shares with him his inexhaustible love for the weak and the poor ${ }^{19}$. This fusion of Aristotelian philosophy with Christian thought brought out in the European civilization, according to Siep, two values of great importance: the Christian virtue of philanthropy and the notion of social care ${ }^{20}$.

Along with the transcendental conception of dignity, we have the inherent conception of it. If the man of classical antiquity, according to Siep, had dignity because he could transcend his material self and reach gods, the man of modernity is focused on his bodily, finite existence and does not need any intellectual or divine support. By virtue of the theoretical use of reason he can acquire knowledge, whereas by virtue of the practical use of reason he can submit his ends to scrutiny and behave moral$1 y^{21}$. On this view, acquiring theoretical knowledge and acting in accordance with the categorical imperative of practical reason is what gives man value and dignity. For man now is not controlled by God's commandments but by his practical reason which prescribes him to foster and promote the ends of others as if they are his own. As Kant puts it: A rational being belongs as a member to the kingdom of ends when he gives universal laws in it but is also himself subject to these laws. He belongs to it as a sovereign when as lawgiving, he is not subject to the will of any other ${ }^{22}$.

Of course, it would be a mistake if we argued that these two conceptions of dignity which Siep has distinguished are so clear-cut and that the former was exclusively developed in antiquity, whereas the latter is a creation of modern times. In his short 
review article entitled "Making sense of dignity", Richard Ashcroft distinguishes in our contemporary era four conceptions of dignity ${ }^{23}$. The first group of philosophers considers all "dignity-talk" as useless and incoherent. Among these philosophers he includes Ruth Macklin and almost all the English speaking bioethicists. The second group of philosophers considers the concept of dignity as having family resemblances with the concepts of capabilities and functionings ${ }^{24}$. This approach has been developed by Martha Nussbaum and Amartya Sen. The third group considers the concept of dignity illuminating but it is strictly reducible to autonomy. This is the approach put forward by Deryck Beyleveld and Roger Brownsword ${ }^{25}$. And the fourth group of philosophers claims that dignity is a metaphysical property which is "possessed by all and only human beings, and which serves as a foundation for moral philosophy and human rights"26. This view is mainly represented by the works of the American bioethicist Leon Kass.

Ashcroft believes in a way that both Beyleveld and Brownsword's approach on the one hand Kass' approach on the other constitute a very good answer to Macklin's claim that dignity is a useless concept. Even though Beyleveld and Brownsword tend to agree with her that dignity is grounded in autonomy, nevertheless they go much further than this. They argue that dignity obliges us to respect even those who have lost their autonomy or they may never regain it again, on the grounds that we have duties and obligations towards those who are fragile and vulnerable ${ }^{27}$. This precisely shows that dignity is not reducible to autonomy, it is something more and above it, since it obliges us to treat morally those who lack autonomy.

Similarly, Ashcroft claims that Kass' metaphysical conception of dignity has many problems. One of the main weaknesses he finds is that dignity is taken by Kass to be a primitive concep $\mathrm{t}^{28}$. But, as he points out, if dignity grounds morality and all moral values, then we need an account of dignity which explains the relationship between dignity and the other moral values, the relation between dignity and its physical embodiment etc., an account which Kass obviously does not supply ${ }^{29}$.

But in criticizing Kass' conception of dignity, Ashcroft shows us the right way of understanding dignity. If dignity is not a metaphysical property which is possessed by all human beings, as Kass claims, then one sensibly wonders how else we can conceive of it. Of course, Ashcroft argues that another approach is to think that dignity is a "thick" concept, that is to say a concept that combines descriptive with evaluative meaning ${ }^{30}$. Ashcroft compares the term "dignified" with "rude". He could also have compared it with terms such as "industrious", "courageous", "generous" etc.. ${ }^{31}$ In the case of rude and the other terms we have fairly fixed standards in our society as to what constitutes rudeness, industry, courage, generosity. As a consequence, such terms have firmly attached their descriptive meaning to them; their evaluative meaning is only secondary ${ }^{32}$.

The question I wish to ask is this: Is the meaning of the term "dignified" more like the meaning of the terms "rude", "industrious" etc. or is it more like the meaning of the term "good"? As mentioned, terms like "rude", "industrious" etc. have their descriptive meaning firmly attached to them, this is why they evaluate only in a second- 
ary manner. The term "good", on the other hand, is a primarily evaluative term ${ }^{33}$. It is used primarily to evaluate and only secondarily to describe. This is why its descriptive meaning is never fully fixed. As Hare puts it: Although the evaluative meaning of "good" is primary, the secondary descriptive meaning is never wholly absent ${ }^{34}$.

In fact, the descriptive meaning of the term "good" has to be defined anew each time it is used. To mention Hare's examples, if I talk of "a good egg", then it is fairly clear to which kind of egg I am referring, and which I evaluate as good. If, on the other hand, I talk of "a good poem", the description I am referring to may not be so easy to define $e^{35}$. What remains, however, steady is the evaluative meaning of the term "good" which evaluates whatever the standard of good poetry is which I adopt.

I wish to argue that the logic of the term "dignified" is more like the logic of the term "good" than that of the secondarily evaluative terms. The term "dignified" does not have any fixed descriptive meaning, it is primarily an evaluative term. Its descriptive meaning is defined from the beginning each time it is attributed to someone. So if I talk of "a dignified public servant", I understand very well the kind of description I am referring to, that is the public servant that is in his office the precise hours, that performs his expected duties conscientiously, that is never bribed, and has good manners. In the same way that if I talk of "a dignified father" or of "a dignified citizen", I understand fully the kind of description I am referring to. But in all these cases, whatever the particular description is which I adopt, when I use the term "dignified", I evaluate the persons in question positively. In this sense, the term "dignified", like the term "good", is a primarily evaluative term.

This lack of specific descriptive meaning that characterizes the primarily evaluative terms has obviously led philosophers, like Macklin and Harris, to argue that dignity is a useless and meaningless concept. (In a way they remind us of the Logical Positivists and of their project that moral language is meaningless). Would these philosophers argue in the same way about good? Would they also argue that "good" is a useless concept? I just wonder. If they also argued that "good", like "dignified", is a useless and meaningless concept, then they evidently have an impoverished conceptual scheme, a scheme that lacks completely evaluative terms. This translated in real terms would mean that in their cosmology and theories of knowledge values have no place. If this is the case, then this would be indeed something deplorable, something which they will have to think about again.

\section{REFERENCES}

1. Ruth Macklin, "Dignity is a useless concept", The British Medical Journal, vol. 327 (2003): 14191420 .

2. Ibid.

3. John Harris, On cloning, Routledge, London and New York, 2004

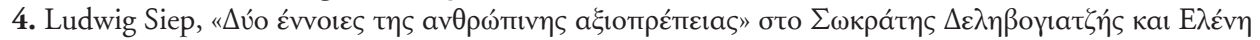

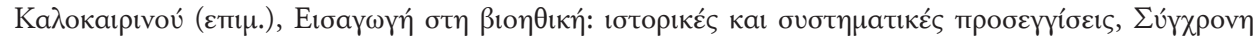

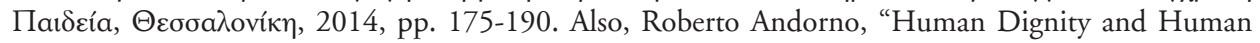
Rights", in Handbook of Global Bioethics, ed. Henk ten Have and Bert Gordijn Springer, Dordrecht, 2014, pp. 45-57. 
5. Andorno, "Human Dignity and Human Rights", pg. 48.

6. Ibid.

7. Ibid.

8. Mirandola, Giovanni Pico Della, Oratio Elegantissima de Dignitate Hominis, transl. in English by Charles Glenn Wallis, The St. John's Bookstore, Annapolis, 1940.

9. Universal Declaration of Human Rights, 1948, www.un.org/en/.../pdf/udhr_booklet_en_web.pdf, accessed on the $30^{\text {th }}$ January 2017.

10. Universal Declaration on Bioethics and Human Rights, UNESCO 2005, unesdoc.unesco.org/images/0014/001461/146 accessed on the $30^{\text {th }}$ January 2017.

11. Universal Declaration on Bioethics and Human Rights, UNESCO, Article 2.c. Also, Roberto Andorno, "Human Dignity and Human Rights as a Common Ground for a Global Bioethics", in the Journal of Medicine and Philosophy, vol. 34 (2009): 223-240, 227.

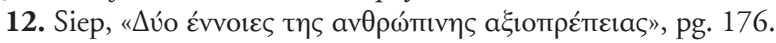

13. Ibid.

14. Ibid.

15. Ibid., pg. 177.

16. Ibid.

17. Ibid.

18. Ibid.

19. Ibid., pg. 178.

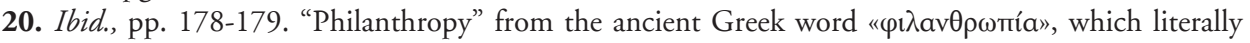
means "love of man".

21. Ibid., pg. 181.

22. Immanuel Kant, Groundwork of the Metaphysics of Morals, Mary Gregor (ed.), Christine M. Korsgaard (introd.), Cambridge University Press, Cambridge, 1997, $\$ 4: 433$.

23. Richard E. Ashcroft, "Making sense of dignity", Journal of Medical Ethics, vol. 31 (2005): 679-682.

24. Ashcroft, "Making sense of dignity", 679.

25. Ibid.

26. Ibid.

27. Ibid., 681.

28. Ibid., 680.

29. Ibid.

30. Ibid.

31. R. M. Hare, The Language of Morals, Oxford University Press, London, Oxford, New York, 1952, pg. 121.

32. R. M. Hare, calls such terms as "rude", "industrious", "courageous", "generous" secondarily evaluative terms.

33. R. M. Hare, The Language of Morals, chapter 7.

34. Ibid., pp. 121-122.

35. Ibid., pg. 122. 